\title{
Review on Sustainability Management Using Zero Waste Concept for Building Construction
}

\author{
Sakshi Gupta, Rishabh Mahure, Ankit Batra
}

\begin{abstract}
All over the world, construction and demolition (C\&D) waste is generated in enormous amount which leads to various environmental problems. The waste is dumped illegally or into the landfills which degrades the soil and causes pollution. To eliminate the problem of C\&D waste management, the concept of zero waste for building construction has been studied in this work. This study aims at finding out the possible research gaps in the management of construction and demolition waste and extant literature survey was done on the sustainability management using zero waste concept.
\end{abstract}

KEYWORDS- Zero waste, Sustainability, C\&D waste, Construction, Management.

\section{INTRODUCTION AND BACKGROUND}

Eradication of waste by efficiently using the project resources is essential for achieving the state of zero waste. Despite the growing global recognition of the environmental impacts associated with the generation and management of waste across industries, the construction industry continues to generate a large amount of waste. All over the globe 1.3 billion tons per year municipal solid waste is generated which is expected to increase up to 2.2 billion tons per year by 2025 . Construction and demolition debris contributes about $12 \%$ of the total solid waste for any city which is generated during construction, operation and demolition stage of any building. According to the Australian Bureau of Statistics (2010), the construction industry in Australia comprises about 585,000 enterprises and employs about 900,000 people. In total, the industry accounts for approximately 7 per cent of Australia's gross

\section{Manuscript received May 21, 2020}

Sakshi Gupta, Department of Civil Engineering, Amity School of Engineering \& Technology, Amity University Haryana, India-122413 (sgupta6@ggn.amity.edu)

Rishabh Mahure, Dept. of Civil Engg., Noida International University, Gr. Noida, Uttar Pradesh, India

Ankit Batra, Department of Civil Engineering, Amity School of Engineering \& Technology, Amity University Haryana, India-122413 domestic product (GDP). Similarly, the construction industry contributes 6 per cent of the United Kingdom GDP, where it employs more than 2.3 million people. The profitability of the industry can be linked to the effective usage of project resources and, to some extent, the adoption of strategies such as waste management that improve cost-effectiveness through the elimination of waste. As highlighted by Chen (2010) [2] China, the world's biggest developing country, construction activities generate 300 million tonnes of waste annually: 40 per cent of the total amount of that country's waste. Despite the growing recognition of the environmental impacts associated with the generation and management of waste across the construction project life cycle, the implementation of appropriate waste-management strategies towards the total waste management elimination has limited effect. In most of the countries, factors such as lack of infrastructure, financial support and technology which are not up to the required level leading to inefficient waste management services. Further since construction is one of the basic need for development and GDP growth for any country, thus government policies are promoting rapid construction growth. Rapid construction growth with the lack of infrastructure for waste handling is contributing abnormally for waste generation during any construction, maintenance and demolition phases of a building.

Efforts to manage waste has been categorised into four hierarchical orders, known as the waste hierarchy. This involves reduce, re-use, recycle, recover and disposal (Guthrie et al., 1999) [3], with "reduce" and "re-use" offering better environmental and economic benefits. The former seeks to decrease waste generated while the latter deals with reabsorption of the waste generated. Alternatively, when "reduce and re-use" become impracticable, processing of waste materials to produce a derivative product, known as recycling, becomes the best option. Recycling also consumes a substantial amount of energy that results in environmental pollution, waste recycling reduces the need for extracting raw material sand prevents pollution due to mining and production processes. These options are usually expected to be explored before the decision to landfill waste, especially as it results in total economic loss and comes with series of negative environmental impacts, asides nations running out of landfill sites. 


\section{A. Zero Waste Concept:}

Zero Waste is an idea that inspires to re-design the resource life cycles so as to reuse all products. The goal is for no trash to be sent to landfills.. It guide people in changing the construction practices to follow sustainable natural cycles, where all discarded materials are designed to become resources for others to use. Adoption of Zero Waste will remove all ejections to land, water or air that poses danger to environmental, humans, living and non-living creatures or plant health. Zero waste incorporates more than removing waste through recycling and reuse, than on restructuring production and distribution systems to reduce waste and provides guiding principles for continually working towards eliminating wastes.

\section{B.Cradle-to-cradle concept:}

Cradle-to-cradle ( $\mathrm{C} 2 \mathrm{C})$ design is a biomimetic method for the products' design and structures that replicates human engineering on nature's procedures observing materials as nutrients mixing in healthy, and safe metabolisms. C2C suggests that the industry should safeguard and supplement ecosystems and nature's biological metabolism. While doing this, they should also maintain a safe, industrious technical metabolism for the high-quality utilization and transportation of organic and technical nutrients.

Resources on earth are significant and constrained in this way we ought to not simply be discarded after use. A complete drift in waste management practices is required to save our resources for our present and future generations. Concepts such as zero waste construction, cradle-to-cradle must be implemented for all construction activities to protect and enrich ecosystems and nature's biological metabolism.

Other than environmental values, number of other benefits can also be gained by effective waste management during the construction of new buildings and for the retrofitting of existing buildings, such as:

1. Reusing and recycling save landfill sites.

2. Recycling reduces the need for the constant extraction or mining of resources.

3. Flourish recycling industry which can provide large number of employments.

4. Reduces the need for new materials and products.

5. Reduce the usage of energy for producing new raw materials.

6. Cost saving in terms of waste collection, storage, transportation and disposal.

Some studies have identified the need to address the issue of waste management throughout the project life cycle, there is evidence to suggest that the attitude of a large proportion of industry practitioners towards construction and demolition waste is that waste management should only focus on the construction stage. A study by Osmani et al. (2007) discovered that waste management is not significant in the process of designing, as architects revealed that waste is primarily generated during operations at site and infrequently produced during the design process [11]. However, aother study by Poon (2007), dispute this and argue that waste reduction can be achieved through changes in design concepts [12]. A study by Fapohunda et al. (2006) pointed out that resources wastage accounted for 30 per cent of the building cost and implied that construction resource wastefulness affects the achievement of clients', contractors', participants' and other stakeholders' objectives [7]. Given the pressing problem of resource use, there is growing evidence of the need to address waste-management issues at state, national and international levels.

\section{REVIEW ON SUSTAINABILITY MANAGEMENT USING ZERO WASTE CONCEPT}

Nicholas (2012) stated that elimination of waste through the efficient use of project resources is fundamental for a state of zero waste [9]. The links between construction management principles and waste minimization has been explored. Suggested some drivers for achieving zero waste, such as building procurement teams, empowered work teams, lean designing, education and training, awareness of waste-management systems, senior management commitment, technological innovation, changes to organizational culture and individual behaviour change.

Calhoun (2012) studied the operations of C\&D debris recovery facilities. Information provided by the facilities was used to calculate the number of jobs created per ton of C\&D debris material received, the amount of materials recovered from the waste stream, the amount of emissions resulting from fuel usage, and the amount of potential greenhouse gas emissions savings from recycling $\mathrm{C} \& \mathrm{D}$ debris materials versus landfilling them [2].

Stephen (2012) estimated the debris generation over the period of 2001 to 2009 for Florida. The debris generation model was built for a considerable length of time 2001-2010 utilizing territory esteems for C\&D exercises in six areas acquired from building grants and flotsam and jetsam age multipliers. All things considered, concrete $(53 \%)$ drywall $(20 \%)$, wood $(12 \%)$, a different portion (8\%), black-top roofing material (4\%), metal (2\%), cardboard (1\%) and carpet and padding(1\%).A market analysis was performed for concrete, drywall, wood, asphalt roofing shingles and residual screened materials (RSM) [13].

Yang (2012) mentioned that Hydrogen sulfide (H2S) generation in construction and demolition (C\&D) debris landfills has been associated with the biodegradation of gypsum drywall. Laboratory research was conducted to observe $\mathrm{H} 2 \mathrm{~S}$ generation when drywall was co-disposed with different C\&D debris constituents [16]. Two experiments were conducted using simulated landfill columns. Experiment 1 comprised of different mixes of drywall, wood, and cement to decide the effect of various waste constituents and mixes on $\mathrm{H} 2 \mathrm{~S}$ age. Experiment 2 was intended to inspect the impact of cement on $\mathrm{H} 2 \mathrm{~S}$ age and relocation. The results indicate that decaying drywall, even alone, leached enough sulfate ions and organic matter for sulfate-reducing bacteria (SRB) to generate large $\mathrm{H} 2 \mathrm{~S}$ concentrations as high as 63,000 ppmv. The codes-posed wastes show some effect on $\mathrm{H} 2 \mathrm{~S}$ generation. At the end of experiment 1 , the wood/drywall and drywall alone columns possessed H2S concentrations >40,000 ppmv. Conversely, 
$\mathrm{H} 2 \mathrm{~S}$ concentrations were $<1 \mathrm{ppmv}$ in those columns containing concrete. Concrete plays a role in decreasing $\mathrm{H} 2 \mathrm{~S}$ by increasing $\mathrm{pH}$ out of the range for SRB growth and by reacting with $\mathrm{H} 2 \mathrm{~S}$. Study also showed that wood lowered $\mathrm{H} 2 \mathrm{~S}$ concentrations initially by decreasing leachate $\mathrm{pH}$ values. Based on the results, two possible control mechanisms to mitigate $\mathrm{H} 2 \mathrm{~S}$ generation in $\mathrm{C} \& \mathrm{D}$ debris landfills are suggested.

Erkelens (2013) highlighted that different approach to the planning phase results in more materials being left on the site or being re-used, and a change in floor plans leads to more re-use of materials, less waste, and less need for new materials. The achievable reduction of environmental impact can be calculated with Life Cycle Analysis (LCA) calculations. Environmental impact of such renovation projects could be lowered by $5-10 \%$. More precise data on impact of waste reduction will be obtained if LCA is improved [6].

As per ZWIA (2015), Zero Waste is a goal that is ethical, economical, efficient and visionary, to guide people in changing their lifestyles and practices to emulate sustainable natural cycles, where all discarded materials are designed to become resources for others to use. Zero Waste means designing and managing products and processes to systematically avoid and eliminate the volume and toxicity of waste and materials, conserve and recover all resources, and not burn or bury them. Implementing Zero Waste will eliminate all discharges to land, water or air that are a threat to planetary, human, animal or plant health [18].

Elgizawy (2016) highlighted that Construction and demolition waste differs according to the location and type of the project [5]. A comprehensive list of construction and demolition waste stream was formulated to study the end life of each of the components of the construction and demolition waste stream and their reuse or recycling option. A picture of $\mathrm{C} \& \mathrm{D}$ waste classification methods, its components and their end of life treatment evaluated.

Tiwary (2016) evaluated the properties of the C\&D waste and estimate the possible landfill volume gain from the diversion of $C \& D$ waste. Five construction and five demolition waste samples were collected from the City of Denton landfill in October 2015 [14]. Based on the manual sorting of the samples, the average composition for the C\&D waste with equal proportion of construction waste and demolition waste $(50 \%$ Construction and $50 \%$ demolition waste) was found to consist of $36.6 \%$ wood products, $18.3 \%$ Portland cement concrete, $10 \%$ asphalt concrete, $12 \%$ brick and tiles, $1.3 \%$ metals, $11 \%$ drywall \& plaster, 5\% cardboard, and $6 \% \mathrm{C} \& \mathrm{D}$ debris fine. The unit weights of the collected samples were determined using the standard proctor method. For C\&D waste with equal proportion of construction waste and demolition waste $(50 \%$ Construction and $50 \%$ demolition waste), the unit weight was found to be 62.13 pcf ( 0.84 tons per cubic yard). The average moisture content of construction waste was determined to be $5.93 \%$ and $6.33 \%$ on wet weight and dry weight basis respectively. Whereas, the average moisture content for demolition waste was found to be $2.73 \%$ and $2.81 \%$ on wet weight and dry weight basis respectively. The volatile solids content of construction waste was found to be $82.7 \%$ in average. The landfill volume gain was estimated based on the average annual tonnage and unit weight from the current study. Based on the results, for a landfill with 20 acres area, 100 feet design height and $3 \mathrm{H}: 1 \mathrm{~V}$ side slope, approximately $1.25 \%$ of total landfill volume which is approximately equal to $0.61 \%$ of total lift height can be obtained per year by diverting $90 \%$ of the C\&D waste from the landfill 15,17].

Omar (2017) highlighted the Cradle-to-Cradle approach, Cleaner Production, Industrial Ecology, Eco-Industrial Park and Environmentally Balanced Industrial Complex that help towards sustainable industrial community and reach zero pollution [9].

Cochran (2017) explored the methodology for the accounting, generation, and composition of building-related construction and demolition. Six detailed categories of debris were scrutinized and observed: residential construction, non-residential construction, residential demolition, non-residential demolition, residential renovation, and non-residential renovation [4]. Debris produced from each activity was calculated as the product of the total area of activity and waste generated per unit area of activity and summarized as concrete represented $56 \%$, wood $13 \%$, drywall $11 \%$, miscellaneous debris $8 \%$, asphalt roofing materials $7 \%$, metal $3 \%$, cardboard 1\%, and plastic Bansal (2016) [21] elaborated that use of $C \& D$ waste save huge amount of natural resources, diminish $\mathrm{CO}_{2}$ footprint, decrease the environmental pollution, diminish environmental impact, generate some space in the urban localities by reusing, decrease of huge area essential for sites and generation of job and business prospects across the world.

Thus, from the literature studied, the following points are summarized:

1. Large amount of work has been done in field of reduce and reuse of the construction waste which is getting generated during construction process but no work on zero waste management has been taken place in India especially. 2. Activities were identified in construction process and efforts were made to reuse the waste generated in other activities.

3. Research was also carried out in field of construction design, keeping in a view for ease of construction and utilization of material to maximum extent, ensuring waste minimization.

\section{DISCUSSION AND FUTURE WORK}

The above series of studies lacked vigour by failing to produce a holistic approach that covers all stages of project delivery process. As such, there is a need for a dynamic approach in looking into the relationship between main waste-efficient indicators at design, procurement and construction stages. This would not only establish impacts 
of one waste mitigation strategy on other, but it is also expected to provide practitioners with an optimum approach to prevent waste causative factors from design to completion.

Zero waste strategy shows that waste needs to move from a linear to cyclic system in accordance with the cradle to cradle approach so as to utilize the materials efficiently. The overall aim of this study is to develop the design, procurement and construction strategies for minimising waste in construction industrial project of large scale comprises of number of different type of buildings, roads, drains and landscaping. Apart from an investigation of the key and underlying measures for construction waste mitigation, we will examines the interrelationship between stages of projects' lifecycle, as activities carried out at an earlier stage is capable of engendering occurrences at later stages. In a bid to accomplish this aim, the following can be adopted for further studies:

[1] To model the project design and execution methodologies to ensure minimum waste generation during construction activities.

[2] To prepare a work methodology for reusing all kind of generated construction wastage within the project to achieve the objective of zero waste construction.

[3] To quantify and achieve level of construction cost reduction using zero waste concept.

Also, Cost optimization can be targeted by ensuring optimum usage of all resources within the project and further by exploring the usage of waste material as a substitute of basic construction material. This would help in further direction of waste which get involves due to damages or other physical activities during operations stage in a construction project.

\section{ACKNOWLEDGMENT}

The authors sincerely thanks their institution for the support provided. Authors would like to thank all the researchers whose research work helped us in writing this paper.

\section{REFERENCES}

[1] Australian Bureau of Statistics (ABS) (2010) Australia's Environment: Issues and Trends, no 4613.0 Australian Bureau of Statistics, Canberra, Australia.

[2] Calhoun, A. (2012) Impact of construction and demolition debris recovery facilities on job creation and the environment in Florida. University of Florida.

[3] Chen, M. Z., Lin, 1. T., Wu, S. P. \& Liu, C. H. (2010) Utilization of recycled brick powder as alternative filler in asphalt mixture. Construction and Building Materials25, 4, 1532-1536

[4] Cochran, K., Timothy, G., Debra, R. and Howell, H. (2017) Estimation of regional building-related C\&D debris generation and composition: Case study for Florida. Waste Management 27(7): 921-31

[5] Elgizawy, S.M., El-Haggar, S.M. \& Nassar, K. (2016) Approaching Sustainability of Construction and
Demolition Waste Using Zero Waste Concept. Low Carbon Economy, 7, 1-11.

[6] Erkelens, P. A. (2003). Zero waste in renovation. Open House International, 28(1), 83-89.

[7] Fapohunda, J., Stephenson, P., Griffith, A. \& Chileshe, N. (2006) The impact of construction resource wastage on building production, in Conference Proceedings. The First Built Environment Conference, CIOB AFRICA, Association of Schools of Construction of Southern Africa, Johannesburg, South Africa.

[8] Guthrie, P.M., Coventry, S.J. \& Woolveridge, A.C. (1999) Waste minimization and recycling in construction: Technical review. London: CIRIA.

[9] Nicholas, C., Jian Z., Stephen P., and George Z. (2012) Construction management and a state of zero waste. Research gate.

[10] Omar, H. and Salah, H. (2017) Sustainable Industrial Community. Journal of Environmental Protection, 8, 301-318

[11] Osmani, M., Glass, J. \& Price, A. D. F. (2007) Architects perspectives on construction waste reduction by design. Waste Management. 28, 7, 1147-58

[12] Poon, C. S. (2007) Reducing construction waste. Waste Management. 27, 12, 1715-1716.

[13] Stephen, M. (2012) Construction and demolition debris recovery and recycling in orange county, FI. Electronic Theses and Dissertations. 2161.

[14] Tiwary, A. (2016) Landfill Volume Gain from the Diversion of Construction and Demolition Waste, the University Of Texas at Arlington.

[15] Torgal, F. and Labrincha, (2013) A. The future of construction materials research and the seventh UN Millennium Development Goal: A few insights. Construction and Building Materials 40:729-737.

[16] Yang, K., Qigong, X., Timothy, G., Paul, C., Gabriel, B. and Matthew, B. (2012) Hydrogen Sulphide Generation in Simulated Construction and Demolition Debris Landfills: Impact of Waste Composition. Journal of the Air \& Waste Management Association, 56:8, 1130-1138,

[17] Bansal, A., Mishra, G., and Bishop, S., (2016) Recycling And Reuse Of Construction And Demolition Waste: Sustainable Approach, International Conference on Sustainable Built Environment.

[18] Zero Waste International Alliance. (2015), http://zwia.org/standards/zw-definition

\section{ABOUT THE AUTHORS}

Sakshi Gupta, is presently working as Assistant Professor, Department of Civil Engineering, Amity School of Engineering and Technology, Amity University Haryana, India. Her areas of interest includes construction technology and management, BIM, concrete technology, Soft computing techniques in Civil Engineering applications and sustainable construction. She has published more than 40 research articles, paper, book chapters and books of National and International repute. 
She is the editorial as well as reviewer board member of many international journals.

Rishabh Mahure is presently working as Assistant Professor, Department of Civil Engineering, Noida International University, Gr. Noida, UP. He is M.Tech in Construction Technology and management and has an expertise in materials related with concrete. He has published many research papers in journals of national and international repute.

Ankit Batra, is working as Assistant Professor, Department of Civil Engineering, Amity School of Engineering and Technology, Amity University Haryana, India. His area of specialization includes design and analysis of structures. He is competent in various software skills such as ETabs, STAADPro to name a few. He has published various papers in journals of national and international repute. 